\title{
Better Stories Needed: How Meaningful Narratives can Transform the World
}

\author{
Michael Pirson ${ }^{1,2}$
}

Published online: 12 October 2017

(C) Springer International Publishing AG 2017

The world is going through major upheaval and many people feel drawn to despair (Pirson 2017a, b). As George Monbiot ${ }^{1}$ and others suggest our current problems, as intractable as they may seem, rather point to our lack of imagination. It looks like we are experiencing the phase preceding a major paradigm shift and all the crises that go along with it (Kuhn 1996). The dominant paradigm cannot explain the social anomalies and it appears as if outside events such as terrorist attacks, extreme weather or political unrest force our mindsets to shift. As a typical reaction to such threats, people across the world turn to the old and more familiar paradigms hoping to find comfort. The elections of strongmen across the globe show that humanity's tribal instincts have kicked into overdrive. Because we lack an alternative narrative that features a universal purpose in a world of globalization, many people seek solace in the soothing stories of a seemingly glorious tribal past. However, our human need for community and purpose will likely not be satisfied by these returns to tribalism in an increasingly interconnected world.

Creating a universally applicable purpose for a global community is arguably the challenge of our species at this point of time. It is clear that this momentous task requires a lot of imagination and cannot be achieved by anyone person, organization or country alone. It is a large systemic effort of human co-creation. We all need to be able to be part of the solution and achieve a different, and higher level of consciousness. This shift of consciousness has been advocated by many and can be formulated at its core as an understanding of us human beings as deeply connected to one another and the world around us. Chris Laszlo uses insights from quantum physics to show how we are fundamentally connected to each other, nature, and the world around us on a particle level (Laszlo and Tsao 2017). Rather than being distinct individuals in a competitive setting fighting for profit at whatever cost, people thrive when they can act in harmony with their community and environment. This new level of consciousness, however, can only be advanced when we debunk old narratives and create functional alternatives to replace them (Waddock 2016).

${ }^{1}$ https://www.theguardian.com/books/2017/sep/09/george-monbiot-how-de-we-get-out-of-this-mess

Michael Pirson

pirson@fordham.edu

1 Fordham University, New York, NY, USA

2 International Humanistic Management Association, New York, NY, USA 
The most powerful way people have grown, shifted their mindset, and achieved higher levels of consciousness historically has been through stories (Lovins 2016) - ideally stories that help us make sense of the world, give us a shared purpose, and help us learn and embrace the challenges to move forward (Pirson 2016). Religion has successfully used stories to bring solace and allow believers to make sense of their lives. Religion has also provided community and cemented tribal and intertribal bonds. The secular stories that underlie political and economic globalization movement have failed to clearly articulate a meaningful purpose beyond the acquisition of status, power, and wealth (Lawrence and Pirson 2015). The religious revival in the past decades shows the urgent need for deeper purpose, yet it also has created stronger in-groups and outgroups feeding global violence. We thus still need a universal, global story that creates meaningful explanations and can help humanity survive and thrive (Lovins 2016; Waddock 2016).

At the International Humanistic Management Association, we are suggesting that we have elements for a new and better story of how humanity can organize and address these global problems. Those elements are centered on the protection of dignity and the promotion of wellbeing (Pirson 2017a, b). These principles are not novel; in fact, they have stood the test of time: as a species we created risks to our survival precisely when we did not honor these principles resulting in warfare, environmental crises, or genocide. Ancient wisdom traditions have pointed to the importance of treating people humanely and sanctify those that contribute to a higher purpose (Kueng 2004). They also tell stories that celebrate ethical behavior which Hans Küng and others view as a key lever to human survival. Intrinsically ethical behavior understood as management that protects dignity and creates well-being we argue is the most effective practice to 1) ensure survival as a necessary condition and 2) allow for human thriving in harmony with nature (Pirson 2017a, b).

Our current understanding of ethics in business schools, however, views ethics and morality as constraints on otherwise amoral behavior (Amann et al. 2011). We often teach that one should do no harm while maximizing shareholder value or ensure compliance when one trade's financial derivatives (Pirson 2017a, b). On the other hand, science provides increasing evidence that our species has survived as a social, altruistic species in which moral behavior (at least at group level) was key to survival (Lawrence 2010). As such, ethical behavior is more accurately a TO DO guide, a practical application for how we organize better (Dierksmeier et al. 2011).

Since this kind of thinking is considered foreign to most business schools, businesses, and society at large, we need new stories to reconcile our current management approaches with what famed biologist E.O. Wilson calls the consilience of knowledge (Wilson 1998). We are all called to create new stories and new narratives about who we are as human beings and how we organize better. As George Monbiot states:

"It is the realisation that it is not strong leaders or parties that dominate politics as much as powerful political narratives.[...] This should not surprise us. Stories are the means by which we navigate the world. They allow us to interpret its complex and contradictory signals. We all possess a narrative instinct: an innate disposition to listen for an account of who we are and where we stand."2

Hunter Lovins and Sandra Waddock have called for better, more cogent stories. By that they do not mean better Hollywood movies or TV scripts. Even though, it would be worthwhile to

$\overline{{ }^{2} \text { Cf: https://www.theguardian.com/books/2017/sep/09/george-monbiot-how-de-we-get-out-of-this-mess }}$ 
understand our fascination with psychopathic antiheroes such as Tony Soprano of the Mafia Saga "the Sopranos", Frank Underwood in "House of Cards", Walter White of "Breaking Bad", Nucky Johnson of "Boardwalk Empire"...(this list could be continued). In prior editions of the Humanistic Management Journal, Hunter Lovins and Sandra Waddock refer to how systemic change has been brought about in the past. It has always been a shift of stories that we tell each other about what matters and what we should organize towards.

Such shifts in paradigm or narrative have occurred over time. On the European continent, the dominant narrative was provided by the Catholic Church until modern times and the renaissance challenged it. By placing human dignity at the center and employing stories that empowered people to think for themselves the authority structures were reshaped. The economic historian Deirdre McCloskey argues that the main shift towards Western, capitalist economics has occurred by embracing entrepreneurial problem solving as a dignified activity. When before, moneymaking was considered a second class activity relegated to minorities, a new story of democratic empowerment and achievement led the path to Western progress, she argues (McCloskey 2010). A shift of the cultural narrative was arguably the lever for change. The story changed once more when Marx reframed capitalist activity as exploitation. The lack of dignity of a large proportion of workers led to the transformation in worldview and in societal structure. Rescuing economic freedom from Marxist claims and Keynesian state intervention, the Mont Pelerin Society later advocated for a "free" market (Lawrence and Pirson 2015; Lovins 2016; Waddock 2016). A very powerful meme of a story that is now called neo-liberalism. These are just some examples that show how science and research has influenced the stories we tell about who we are, what we consider important, and what we wish to organize for.

Of course, a call for narratives and stories could be viewed as blasphemous or simply naïve because social science legitimizes itself by being objective and fact-based. The emergence of "fake news" as a relevant phenomenon points to the power of stories that are imagined, fact free, and primarily engineered to gain power. The consilience of science predicted by E.O Wilson, however, provides a novel starting point for both the scientific, fact-based approach in connection with the more subjective and faith- based approach to such narratives. While it is a risky endeavor, it seems nevertheless worthwhile. Exploring the underlying patterns of how we see our world is important. Even more so, because we need to understand how we can shift our worldview to better enable our survival as a species.

The stories we tell each other matter. They allow us to engage with what we consider legitimate and relevant. What is it that we recognize and value in our stories of our shared cultural narratives? It is important that examine with rigor the stories we tell about ourselves as human beings and our connection with each other and nature at large. At this point of time, we need to understand which stories frame our endeavors better. Given that humanity's survival as a species is at risk we must unpack misguided frames about who we are and what we organize for.

The Humanistic Management Journal is a place to do so.

\section{Contributions in the Current Issue}

Starting off the latest issue of the Humanistic Management Journal is an article by Jonathan Keir, a fellow at the World Ethos institute (Keir 2017). He develops his thinking on how better management practices can be built on the consensus of the global religious narratives. $\mathrm{He}$ 
develops the path-breaking work of Hans Küng on the World Ethos and highlights how this ethos can become a baseline for global business management. As Keir states; "for Küng, the 'World Ethos' (Weltethos) is a discovery, less of a common letter than of a common spirit among the world's major and minor spiritual and cultural traditions, which he summarises as 'Basic Trust in life and reality' (in German Grundvertrauen or Lebensvertrauen), a yes-saying disposition of love for life 'despite all temptations to reject it'. Without such a basic disposition, Küng argues, 'no one can behave ethically'." As such Keir develops the argument that ethics is a strategically valid tool for organizing better. He also argues that such ethically inspired strategies can engender trust and love and create a culture in which dignity is protected and the whole person can flourish.

Another way of understanding business is presented by Kevin Jackson of Fordham University (Jackson 2017). He presents music as a metaphor for business, and virtuosity as excellence which can be achieved through business. Jackson suggests that business and music, when at their best, embody virtuosity. His article presents the concept of virtuosity in music as an analogue for a deeper understanding of, and for cultivating, virtuosity in business. Among the advantages of undertaking the comparison is the assistance it provides in envisioning business in a new light, a task especially called for in a climate of disillusionment with economic institutions and economic actors. A story of business as searching harmony trough virtuosity is certainly a different way of understanding management.

Looking at management directly as a practice of communication, Marie Noelle Albert and Jean Pierre Perouma of the University of Quebec explore how dialogue can be used to construct narratives (Albert and Perouma 2017). They suggest that such narratives are the foundation of shared purpose and community. The authors use the concept of a "community of persons" to study a large Canadian business using autopraxegraphy. Presenting the results of interventions at this company, the authors describe how the development of dialogues resulted in the creation of a community of people that could be fully human. However, the traditional practice of focusing on productivity was resumed after the intervention to align with the dominant story of business. The authors suggest that that practice led to a disassembly of a community of people and instead devolved to an association of individuals creating a lot of hidden costs.

Staying with the theme of new stories for better management, Christine Unterrainer, Hans Jeppe Jeppesen and Thomas Faurholt Jonsson of Aarhus University examine how distributive leadership guided by common narrative can enable empowerment at all levels (Unterrainer et al. 2017). In their paper, they study distributed leadership agency (DLA) as an activity-based concept which aims to empower leadership throughout the entire organization. The authors suggest that by combining a descriptive and a normative approach, DLA has the potential of real employee empowerment as it can protect from arbitrary managerial power and lead to employees' personal development through sharing organizational resources, influencing leadership activities and joint decision making in companies. Their study examines individually perceived autonomy as an antecedent and employees' occupational self-efficacy as an outcome of DLA over time. Their results provide first evidence that structural features such as autonomy precede DLA which in turn makes employees better at their job. Overall this paper points to the relevance of perceived dignity as autonomous human being in the decision making process.

In a final contribution, Michel Dion of Sherbrooke University examines sustainability reports as would be narratives of an organization's future (Dion 2017). Dion explores how corporate citizenship, social responsibility, and sustainability reports could be analyzed from a 
philosophical viewpoint. In his article, he uses Paul Ricoeur's hermeneutic philosophy to assess the narrativity of such reports. Out of a philosophical viewpoint, the exploratory study analyzes the contents of ten reports: two corporate citizenship reports (Disney; Abbott), three corporate social responsibility reports (WhiteWave; Comcast NBCUniversal; MGM Resorts International), and five sustainability reports (Whole Foods Market; Marriott; Johnson \& Johnson; Toyota; Honda). Those reports are arising in-time and are thus referring to past corporate events and phenomena (past-focused perspective). Sometimes such reports introduce a corporate world-dream that could emphasize various issues such as human dignity and inclusiveness/diversity, global health, and planetary stewardship (future-focused perspective). They could even convey a subversive ideal that could strongly shake the foundations of business. The way business corporations are understanding corporate citizenship and sustainability could, more or less radically, change the way we are doing business. However, those corporate citizenship, social responsibility and sustainability reports do not have any emplotment. They are thus stories that cannot be considered as narratives. We could call them "would-be" narratives. As we can see the narrative perspective on management can help to see business differently. As Dion argues, organizations could benefit from using this perspective even more.

I hope you can see the contributions in this issue as helpful stepping-stones. They can inform further research into the importance of "stories", paradigms or narratives, and how mindsets can shape our responses to the current global managerial challenges. We are looking forward to receiving your submissions.

\section{References}

Albert, M., and J. Perouma. 2017. The Dialogue: an Essential Component to Consider Organization as a Community of Persons. Humanistic Management Journal 2 (1). https://doi.org/10.1007/s41463-4101740024-41468.

Amann, W., et al., eds. 2011. Business Schools Under Fire: Humanistic Management Education as the Way Forward Humanism in Business. New York: Palgrave Mcmillan.

Dierksmeier, C., et al., eds. 2011. Humanistic Ethics in the Age of Globality. Humanism in Business. London: Palgrave.

Dion, M. 2017. Corporate Citizenship, Social Responsibility, and Sustainability Reports as "Would-be" Narratives. Humanistic Management Journal 2 (1). https://doi.org/10.1007/s41463-41017-40022-x.

Jackson, K. 2017. Music and Virtuosity: a Higher Vision for Business. Humanistic Management Journal 2 (1). https://doi.org/10.1007/s41463-41017-40020-z.

Keir, J. 2017. A World Ethos for Humanistic Management: Love Story or Dialogue Platform. Humanistic Management Journal 2 (1). https://doi.org/10.1007/s41463-41017-40025-41467.

Kueng, H. 2004. Global responsibility: In search of a new world ethic. New York: Wipf and Stock Publishers.

Kuhn, T. 1996. The Structure of Scientific Revolutions. Chicago: University of Chicago Press.

Laszlo, C., and F. Tsao. 2017. Quantum Leadership. Stamford: Stanford University Press.

Lawrence, P. 2010. Driven to Lead: Good, Bad, and Misguided Leadership. San Francisco: Jossey- Bass.

Lawrence, P.R., and M. Pirson. 2015. Economistic and humanistic narratives of leadership in the age of globality: Toward a renewed Darwinian theory of leadership. Journal of Business Ethics 128 (2): 383-394.

Lovins, H. 2016. Needed: A better Story. Humanistic Management Journal 1 (1): 75-90.

McCloskey, D. 2010. Bourgeois Dignity: Why Economics Can't Explain the Modern World. Chicago: University of Chicago.

Pirson, M. 2016. Editorial: Welcome to the Humanistic Management Journal. Humanistic Management Journal 1 (1): $1-7$.

Pirson, M. 2017a. Humanistic Management-Protecting Dignity and Promoting Well Being. Cambridge: Cambridge University Press.

Pirson, M. 2017b. In a Time of Global Upheaval-Humanistic Management Thinking Needed More Than Ever. Humanistic Management Journal 1 (2): 1-3. 
Unterrainer, C., et al. 2017. Distributed Leadership Agency and Its Relationship to Individual Autonomy and Occupational Self-Efficacy: a Two Wave-Mediation Study in Denmark. Humanistic Management Journal 2 (1). https://doi.org/10.1007/s41463-41017-40023-41469.

Waddock, S. 2016. Foundational Memes for a New Narrative About the Role of Business in Society. Humanistic Management Journal 1 (1): 91-105.

Wilson, E.O. 1998. Consilience : the unity of knowledge. New York, Knopf: Distributed by Random House. 